\title{
MYD88 Gene Mutation Negative
}

National Cancer Institute

\section{Source}

National Cancer Institute. MYD88 Gene Mutation Negative. NCI Thesaurus. Code C148094.

A genetic finding indicating that MYD88 gene mutations have not been detected in a sample. 